\title{
Proyeksi Pertumbuhan Mobil Pribadi Roda Empat (Plat Hitam) Kota Manado Menggunakan Persamaan Differensial Model Pertumbuhan Populasi Kontinu (Model Logistik)
}

\author{
Kartika Hala ${ }^{1}$, Yantje D. Prang ${ }^{2}$, Hanny Komalig ${ }^{3 *}$ \\ 1,2,3 Program Studi Matematika, Fakultas Matematika dan Ilmu Pengetahuan Alam, \\ Universitas Sam Ratulangi Manado \\ *corresponding author email : hanoy07@yahoo.com
}

\begin{abstract}
Abstrak
Proyeksi populasi merupakan proses perhitungan jumlah populasi dimasa yang akan datang berdasarkan asumsi arah perkembangan natalitas (kelahiran), mortalitas (kematian) dan mobilitas (migrasi). Model populasi logistik mengasumsikan bahwa pada waktu tertentu jumlah populasi akan mendekati titik keseimbangan (equilibrium). Penelitian ini bertujuan untuk mengaplikasikan model Persamaan Diferensial Kontinu Model Logistik yang dipakai untuk memprediksikan tingkat pertumbuhan mobil pribadi roda empat plat hitam kota Manado. Berdasarkan data yang diperoleh dari POLDA Sulut, Kantor Samsat Manado dan Kantor Dinas Perhubungan Kota Manado, maka diasumsikan batas tampung (K) yaitu 18.500 unit mobil. Hasil penelitian ini menunjukan bahwa model yang akurat untuk dipakai dalam meramalkan tingkat pertumbuhan mobil pribadi roda empat plat hitam yaitu model dengan $k=0,9837, P=\frac{18500}{1+(3,995949) e^{-(0,98372) t}}$ dengan tingkat laju pertumbuhan relatif $98,73 \%$ pertahunnya. Berdasarkan model tersebut tingkat pertumbuhan mobil pribadi roda empat plat hitam tahun 2020 yaitu 18496 unit mobil.
\end{abstract}

Kata kunci : Proyeksi populasi, Persamaan Diferensial Kontinu, Populasi Logistik, Tingkat pertumbuhan

\section{Growth Projections of Private Cars (Black Plate) in Manado Using Differential Equations with Continuous Population Growth Model (Logistic Model)}

\begin{abstract}
Population projections is the process of calculating the number of population in the future based on assumptions direction birthrate growth (births), mortality (death) and mobility (migration).Logistic population model assumes that at certain times the number of population will approach the point of balance (equilibrium). This study aims to apply the differential equation model of continuous logistic model used to predict the rate of growth of private car plate black four-wheel city of Manado. Based on data obtained from the Police and North Sulawesi, Manado Samsat Office and the Department of Transportation Office of Manado City, it is assumed that the capacity limit $(K)$ ie 18,500 units. These results indicate that an accurate model for use in predicting the growth rate of private car four-wheel black plate is a model with $k=0.98372, P=$ $\frac{18500}{1+(3,995949) e^{-(0,98372) t}}$, level relative growth rate of $98.73 \%$ annually. Based on the model of the growth rate of private car four-wheel black plate 2020 is 18496 units.
\end{abstract}

Keywords: population projections, Differential Equations continuous, Logistics Population, Growth rate

\section{Pendahuluan}

Banyaknya jumlah mobil dikota Manado disebabkan oleh berbagai faktor dimana faktor yang paling utama yaitu pembelian mobil baru yang dipakai dikota Manado. Faktor lainnya yaitu masuknya mobil yang dibeli dari luar kota Manado atau mutasi mobil masuk.

Permasalahan pertumbuhan mobil dikota Manado khususnya mobil plat hitam tersebut sangat menarik untuk diteliti. Dengan mengabaikan plat kuning dan plat merah serta menganggap bahwa pertumbuhan mobil plat hitam bergantung terhadap waktu, maka permasalahan pertumbuhan mobil plat hitam di kota Manado dapat dimodelkan menggunakan persamaan differensial model pertumbuhan populasi kontinu. terdapat dua macam model pertumbuhan populasi kontinu diantaranya model populasi eksponensial dan model populasi logistik [1]. Karena kasus pertumbuhan 
mobil pribadi roda empat plat hitam kota Manado menggunakan kapasitas jalan sebagai batas tampung, maka diasumsikan menggunakan model logistik.

a. Bagaimanakah aplikasi persamaan differensial model populasi kontinu (logistik) pada tingkat pertumbuhan pengguna mobil pribadi roda empat plat hitam dikota Manado ?

b. Apakah akurat model populasi kontinu (logistik) yang digunakan untuk memprediksikan tingkat pertumbuhan mobil pribadi roda empat plat hitam dikota Manado ?

c. Bagaimanakah tingkat pertumbuhan mobil pribadi roda empat plat hitam dikota Manado pada tahun 2020 ?

\section{Model Pertumbuhan Populasi}

Untuk mengurangi dampak negatif dari pertumbuhan suatu populasi maka salah satu solusi yang dapat ditempuh adalah proyeksi pertumbuhan dari populasi tersebut. Proyeksi populasi merupakan proses perhitungan jumlah populasi dimasa yang akan datang berdasarkan asumsi arah perkembangan natalitas (kelahiran), mortalitas (kematian) dan mobilitas (migrasi) [2].

Ada beberapa model yang biasa dipakai untuk menghitung pertumbuhan populasi, salah satunya model persamaan diferensial kontinu yang dipakai untuk memprediksikan pertumbuhan populasi pada tahun-tahun berikutnya. Model persamaan diferensial kontinu terbagi atas 2 model yaitu model Malthus (model eksponensial) dan model Verhulst (model logistik). Model Verhulst atau model logistik mengasumsikan bahwa pada waktu tertentu jumlah populasi akan mendekati titik keseimbangan (equilibrium). Pada titik ini jumlah kelahiran dan kematian dianggap sama sehingga grafiknya mendekati konstan [3].

Dari asumsi tersebut, maka diperoleh model untuk pertumbuhan populasi yang dikenal Persamaan Diferensial Logistik :

$$
\frac{d P}{d t}=k P\left(1-\frac{P}{K}\right)
$$

Dari persamaan diatas, diasumsikan bahwa jika nilai $P$ kurangnya nilai $K$, maka hasil $P / K$ mendekati 0 dan nilai $d P / d t$ sebanding dengan hasil $k P$. Namun jika nilai $P$ mendekati nilai $K$, maka nilai $P / K$ mendekati 1 , sehingga nilai $d P / d t$ mendekati 0 . Jika populasi $\mathrm{P}$ berada diantara nilai 0 dan nilai $\mathrm{K}$, maka ruas kanan persamaan diatas bernilai positif, sehingga nilai $d P / d t$ mendekati 0 dan populasi naik. Tetapi jika populasi $\mathrm{P}$ lebih besar dari kapasitas tampung $\mathrm{K}$, maka hasil dari $(1-P / K)$ adalah negatif, sehingga nilai $d P / d t$ kurang dari 0 dan populasi turun.

Dari asumsi tersebut, maka diperoleh solusi persamaan logistik sebagai berikut :

Ket: $\quad P(\mathrm{t}) \quad$ : jumlah populasi pada saat $t$

$$
P(t)=\frac{K}{1+\left(\frac{K}{P_{0}}-1\right) e^{-k t}}[4] .
$$

$P_{0} \quad$ : jumlah populasi awal saat $t=0$

$K \quad$ : daya tampung dari suatu daerah untuk populasi

$k \quad:$ laju pertumbuhan perkapita populasi

$t \quad:$ waktu

\section{Metodologi Penelitian}

Data yang digunakan dalam penelitian ini adalah data sekunder yang diperoleh dari POLDA Sulut, Kantor Samsat Manado dan Kantor Dinas Perhubungan Kota Manado. Variabel yang akan digunakan adalah jumlah mobil pribadi roda empat plat hitam.

Dalam penelitian ini menggunakan Persamaan Diferensial Model Populasi Kontinu. Yang akan di analisis adalah pertumbuhan mobil pribadi roda empat di kota Manado dengan menghasilkan model populasi kontinu model logistik untuk memprediksi jumlah mobil pribadi roda empat di tahun berikutnya.

Langkah awal yang dilakukan oleh peneliti adalah mengumpulkan data mengenai jumlah mobil roda empat plat hitam dari tahun 2010 sampai tahun 2015 dan data kapasitas jalan kota Manado. Selanjutnya mencari nilai laju pertumbuhan setiap tahunnya. Hasil akhir yang diperoleh adalah model populasi logistik yang diasumsikan cocok untuk dipakai untuk memprediksi tingkat pertumbuhan ditahun berikutnya. 


\section{Hasil Dan Pembahasan}

\subsection{Data Jumlah Mobil Pribadi Roda Empat di Kota Manado}

Berdasarkan data yang diperoleh dari kantor POLDA Sulut dan kantor Samsat Manado dapat dilihat pertumbuhan mobil pribadi roda empat kota Manado seperti pada tabel 1.

Tabel 1. Jumlah Mobil Pribadi Roda Empat Kota Manado (Satuan Unit )
\begin{tabular}{|c|c|}
\hline Tahun & Jumlah Mobil Pribadi Roda Empat \\
\hline 2010 & 3703 \\
\hline 2011 & 8045 \\
\hline 2012 & 12594 \\
\hline 2013 & 17448 \\
\hline 2014 & 18485 \\
\hline 2015 & 17975 \\
\hline
\end{tabular}

Berdasarkan data yang di peroleh dari Kantor Dinas Perhubungan kota Manado, kapasitas tampung kendaraan kurang lebih 12.860 unit mobil pribadi roda empat atau 38.580,93 m dengan panjang rata-rata mobil $3 \mathrm{~m} /$ unit.

\subsection{Konstruksi Model Populasi Logistik}

Model populasi logistik dalam penelitian ini menggunakan beberapa asumsi berikut:

1. Populasi kontinu terhadap waktu.

2. Semua mobil yang terjual di kota Manado, dianggap dipakai di kota Manado kecuali yang termasuk mobil mutasi keluar.

3. Tidak mempedulikan kasus kehilangan mobil dan sejenisnya.

4. Menggunakan kapasitas tampung perkiraan/dugaan berdasarkan data yang ada dengan melihat data tertinggi.

5. Model yang dipakai untuk memprediksi tingkat pertumbuhan ditahun berikunya adalah model yang hasil pengujian modelnya hampir mendekati data sebenarnya.

\subsection{Estimasi Model Populasi Logistik}

Dengan menganggap jumlah mobil pribadi tahun 2010 sebagai jumlah awal dengan $t=0$, maka selanjutnya menentukan kapasitas tampung $\mathrm{K}$ yang akan digunakan. Dengan mengambil kapasitas tampung 18500 Maka model logistik yang menjadi:

$$
P=\frac{18500}{1+(3,995949) e^{-k t}}
$$

Dari persamaan diatas, akan dicari nilai $k$ yang baru yang dapat mewakili laju pertumbuhan mobil pribadi plat hitam di kota Manado setiap tahunnya dengan hasil sebagai berikut:

1. Model Logistik dengan $k=1,12325$, maka bentuk persamaannya menjadi :

$$
P=\frac{18500}{1+(3,995949) e^{-(1,12325) t}}
$$

dengan laju pertumbuhan relatifnya per tahun sekitar 112,33\%

2. Model Logistik dengan $k=1,07127$, maka bentuk persamaannya menjadi :

$$
P=\frac{18500}{1+(3,995949) e^{-(1,07127) t}}
$$

dengan laju pertumbuhan relatifnya per tahun sekitar 107,13\%

3. Model Logistik dengan $k=1,39794$, maka bentuk persamaannya menjadi :

$$
P=\frac{18500}{1+(3,995949) e^{-(1,39794) t}}
$$

dengan laju pertumbuhan relatifnya per tahun sekitar $139,79 \%$

4. Model Logistik dengan $k=2,12549$, maka bentuk persamaannya menjadi :

$$
P=\frac{18500}{1+(3,995949) e^{-(2,12549) t}}
$$

dengan laju pertumbuhan relatifnya per tahun sekitar 212,55\%

5. Model Logistik dengan $k=0,98372$, maka bentuk persamaannya menjadi : 


$$
P=\frac{18500}{1+(3,995949) e^{-(0,98372) t}}
$$

dengan laju pertumbuhan relatifnya per tahun sekitar $98,37 \%$

\subsection{Pengujian Model Logistik}

Selanjutnya, untuk menguji keakuratan model yang diperoleh maka model yang telah diperoleh kemudian dipakai memproyeksikan jumlah mobil pribadi plat hitam kota Manado dari tahun 2010 sampai 2015.

Berikut tabel dan grafik hasil pengujian model logistik :

Tabel 2. Hasil Pengujian Model Logistik

\begin{tabular}{|c|c|c|c|c|c|c|}
\hline \multirow[b]{2}{*}{ Tahun } & \multirow{2}{*}{$\begin{array}{c}\text { Data } \\
\text { sebenarnya }\end{array}$} & \multicolumn{5}{|c|}{ Hasil Model Logistik dengan $\mathrm{K}=18500$} \\
\hline & & $k=1,12325$ & $k=1,07127$ & $k=1,39794$ & $k=2,12549$ & $k=0,98372$ \\
\hline 2010 & 3703 & 3703 & 3703 & 3703 & 3703 & 3703 \\
\hline 2011 & 8045 & 8044,99 & 7809,52 & 9308,55 & 12525,27 & 7417,34 \\
\hline 2012 & 12594 & 13003,93 & 12594,03 & 14871,42 & 17503,3 & 11868,93 \\
\hline 2013 & 17448 & 16264,4 & 15939,35 & 17448,01 & 18375,09 & 15303,11 \\
\hline 2014 & 18485 & 17708,39 & 17534,98 & 18228,42 & 18485 & 17159,61 \\
\hline 2015 & 17975 & 18234,9 & 18157,67 & 18432,14 & 18498,21 & 17974,99 \\
\hline
\end{tabular}

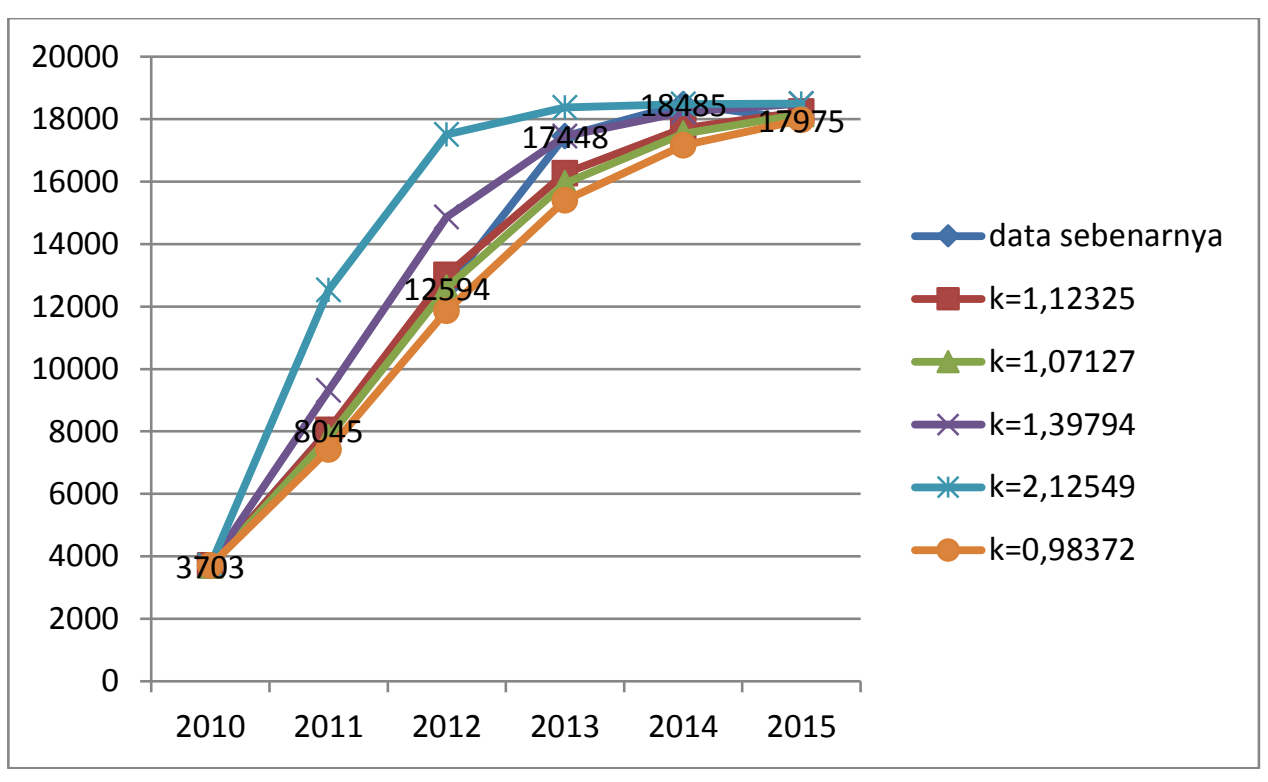

Gambar 2. Grafik Garis Hasil Pengujian Model Logistik

Dengan mengambil hasil uji yang paling mendekati data sebenarnya, maka model dengan $k$ (laju pertumbuhan) yang akan dipakai untuk peramalan tingkat pertumbuhan mobil pribadi roda empat plat hitam tahun berikutnya yaitu model dengan $k=0,98372$ dengan laju pertumbuhan relatif pertahunnya sekitar $98,73 \%$.

\section{Kesimpulan dan Saran}

\subsection{Kesimpulan} bahwa:

Berdasarkan hasil dan pembahasan yang telah diperoleh maka dapat ditarik kesimpulan

1. Mengaplikasikan persamaan diferensial model populasi kontinu pada pertumbuhan mobil pribadi roda empat plat hitam dikota Manado pada saat sekarang ini, dikatakan masih kurang tepat karena jumlah kendaraan yang sudah melebihi kapasitas tampung $(\mathrm{P}(\mathrm{t})>\mathrm{K})$.

2. Model populasi logistik yang dipakai dalam meramalkan tingkat pertumbuhan pengguna mobil pribadi roda empat dikota Manado yaitu model dengan $k=0,98372$ dengan hasil uji model yaitu 17974,99 dan data sebenarnya yaitu 17975 dengan tingkat laju pertumbuhan 
relatif $98,73 \%$ pertahunnya. Model ini diasumsikan akurat karena berdasarkan hasil pengujian model, hasil uji tidak melebihi data sebenarnya.

3. Tingkat pertumbuhan mobil pribadi roda empat plat hitam tahun 2020 berdasarkan model 5 yaitu 18496 unit mobil.

\subsection{Saran}

Sebaiknya pemerintah kota Manado membatasi mutasi mobil masuk ke kota Manado serta membatasi pembelian atau kepemilikan mobil untuk setiap keluarga di kota Manado. Selain itu, untuk mahasiswa yang ingin mengembangkan hasil penelitian ini disarankan untuk mencoba metode lainnya.

\section{Daftar Pustaka}

[1] Afrinisrina. 2010. Aplikasi Persamaan Differensial Model Populasi Kontinu Pada Pertumbuhan Penduduk Jombang. jurnal. STKIP PGRI Jombang. http://sejurnal.stkipjb.ac.id/index.php/AS/article/viewFile/190/126 [diakses 5 Mei 2016]

[2] Khaqim, L, Kwardiniya, A. 2013. Proyeksi Penduduk Provinsi DKI Jakarta dan Kota Surabaya Dengan Model Pertumbuhan Logistik. Jurnal Mahasiswa Matematika. 1 (3) : 232 - 235.

[3] Angraini. 2013. Pemodelan Matematika. Bukit tinggi. http://reniangraini21.blogspot.co.id/2013/11/pemodelan-matematika.html.[diakses 20April 2016].

[4] Stewart, J. 2003. Kalkulus Edisi ke-4 Jilid 2. Erlangga. Jakarta. 